\title{
Genotoxic and Cytotoxic Potential of Smoke Crack Cocaine on the Epithelium of the Human Oral Mucosa
}

\author{
Raphaela Cássia de Lima1, Priscila Ferraz ${ }^{1}$, Cassiano Lima Chaiben², Ângela Fernandes ${ }^{3}$, \\ Ana Maria Trindade Grégio ${ }^{4}$, Maria Ângela Naval Machado ${ }^{3}$, Luciana Reis Azevedo-Alanis ${ }^{4}$, \\ Antonio Adilson Soares de Lima ${ }^{3}$
}

${ }^{1}$ Undergraduate Program - Department of Stomatology - Federal University of Paraná, Curitiba/PR Brazil

${ }^{2}$ Graduate Program - Department of Stomatology - Federal University of Paraná, Curitiba/PR Brazil

${ }^{3}$ Department of Stomatology - Federal University of Paraná, Curitiba/PR Brazil

${ }^{4}$ School of Health and Biosciences-Pontifical Catholic University of Paraná, Curitiba/PR Brazil

Correspondence e-mail to: aas.lima@ufpr.br

\begin{abstract}
Crack cocaine is an illicit drug derived from cocaine. It can produce some damages to the lungs and oral cavity. Objective: The aim of this study was to analyze the frequency of micronuclei and some nuclear alterations in epithelial cells of crack cocaine users. Methods: Oral smears were collected from clinically normal-appearing buccal mucosa exfoliative cytology of 30 individuals (15 crack cocaine users and 15 controls). Results: Crack cocaine users consumed about 3.8 grams per day and the time consumption of the drug was of $6.4 \pm 3.3$ years. The prevalence of micronuclei, binucleated cells, broken egg cells, budding cells, picnosis, karyolysis, and karyorrhexis was determined. The frequencies of micronuclei for case and control groups were, $2.87 \pm 3.46$ and $0.57 \pm 1.6(\mathrm{p}=0.018)$ respectively. No statistical difference was observed for binucleated cells, broken egg cells, budding cells, picnosis, and karyolysis. The frequency of karyorrhexis was significantly increased on crack cocaine users than controls $(54.07 \pm 38.58$ and $24.87 \pm 23.97, p=0.001)$. Conclusion: Smoke crack might have a cytotoxic and genotoxic effects to the oral mucosa due to increased frequency of micronuclei and karyorrhexis. Thus, individuals who used crack cocaine in the long term need to be frequently examined in order to prevent neoplastic transformation.
\end{abstract}

Keywords: carcinogens, crack cocaine, cytological techniques, micronucleus tests, oral mucosa

\section{INTRODUCTION}

The last World Drug Report has estimated that almost a quarter of a billion people between the ages of 15 and 64 years used an illicit drug in 2013. This corresponds to a global prevalence of 5.2\% (range: $3.4-7.0 \%$ ). Cannabis remains the illicit drug most used in the world. However, there are other illicit drugs that are often consumed in certain regions of the world. ${ }^{1}$ One of these drugs is the crack which is the smokable form of cocaine. It has high potential to generate several damage to the user's health. ${ }^{2,3}$ This illicit drug is a potent stimulant of the central nervous system with a high potential for addiction. ${ }^{4}$
Several important histopathological changes have been identified in the epithelium of the tracheobronchial mucosa of crack users, including: basal cell hyperplasia, squamous metaplasia, mitotic figures, nuclear morphology changes, increased nucleus/cytoplasm, basement membrane thickening and inflammation submucosa. ${ }^{5}$ Moreover, these pathological changes become even more frequent when the crack users consume other drugs associated with carcinogenic potential, such as tobacco and alcohol. Thus, crack users may appear as candidates for the development of cancer, including oral cancer. 
The micronucleus test allows identification of an increased frequency of mutations in cells that were exposed to a wide variety of genotoxic agents. This test has been used routinely in the monitoring of individuals potentially exposed to genotoxic agents in chemoprevention protocols and the development of malignancies of the upper aerodigestive. ${ }^{6,7}$ The micronucleus is an additional nucleus which is separate from the main nucleus of a cell. It consists of chromosomes or chromosome fragments that were not included in the main nucleus during mitosis. ${ }^{8-10}$ Its formation is due to spontaneous chromosomal structural changes or due to environmental factors. ${ }^{8}$ Several studies corroborate the effectiveness of the micronucleus cytogenetic assay as an indicator of damage to the oral, bronchial and esophageal epithelial cells. ${ }^{12}$ An increase in micronucleus rate of the oral mucosa is indicative of increase in mutation rates and is related to the development of carcinoma of the oral mucosa. ${ }^{12-14}$

The micronucleus test is considered a fast, inexpensive and non-invasive procedure. It can be repeated several times for the prevention and monitoring of individuals at risk for cancer, such as: chronic users of alcohol, smoking and / or other mutagenic substances. ${ }^{15-18}$ The presence of micronuclei in exfoliated cells of oral mucosa reflects genotoxic events that occurred in cells that were in the basal layer of the epithelium 1-3 weeks before getting the smear. ${ }^{13}$ Until the present date, there are few reports in the literature on the possible genotoxic and cytotoxic effects of crack that is often used with other drugs, such as cigarettes and alcohol (carcinogens). Thus, the aim of this study was to investigate whether smoke crack have genotoxic and / or cytotoxic on human oral mucosa.

\section{METHODS}

The research project was approved by the Committee of Research Ethics of the Universidade Federal do Paraná (CEP/SD 681.016.09.03).

\section{Patients}

Fifteen male crack cocaine users (case group) and fifteen men nonusers (control group) participated in this study. The case group was composed of patients who were hospitalized at the Instituto de Pesquisa e Tratamento do Alcoolism - IPTA (Campo Largo/ PR Brazil). They were in treatment for crack cocaine detoxification for less than one week.

The following inclusion criteria were used to identify individuals for the case group:: a) have been smoking crack, b) have used daily minimum of 1.8 grams of crack in recent months before admission, c) have been smoking crack more a year, and d) not present injuries in the region where the collection of the cells was made. The control group consisted of 15 subjects male
Table 1. Frequency micronucleus and nuclear changes in oral mucosa of crack cocaine users and non-users

\begin{tabular}{lclll}
\hline $\begin{array}{l}\text { Nuclear } \\
\text { alteratinos }\end{array}$ & $\mathrm{N}$ & $\begin{array}{l}\text { Crack cocain } \\
\text { users } \\
\text { Mean } \pm \text { SD }\end{array}$ & $\begin{array}{l}\text { Control } \\
\text { Mean } \pm \text { SD }\end{array}$ & P value \\
\hline Micronucleus & 15 & $2.87 \pm 3.46$ & $0.57 \pm 1.60$ & $0.018^{*}$ \\
Karyolysis & 15 & $26.73 \pm 39.57$ & $8.27 \pm 9.30$ & 0.287 \\
Karyorrhexis & 15 & $54.07 \pm 38.58$ & $24.87 \pm 23.97$ & $0.001^{*}$ \\
Picnosis & 15 & $13.13 \pm 8.81$ & $10.80 \pm 6.79$ & 0.424 \\
Broken eggs & 15 & $27.47 \pm 11.54$ & $25.93 \pm 3.46$ & 0.656 \\
Buds & 15 & $4.07 \pm 3.37$ & $5.00 \pm 5.79$ & 0.867 \\
$\begin{array}{l}\text { Binucleate } \\
\text { cells }\end{array}$ & 15 & $11.13 \pm 6.48$ & $9.33 \pm 6.79$ & 0.464 \\
\hline
\end{tabular}

*Mann-Whitney $\mathrm{p} \leq 0.05$

**Student t-test $\mathrm{p} \leq 0.05$

volunteers who had good conditions of oral and general health and without crack consumption history or any other type of drug.

\section{Collection of samples}

Oral epithelial cells were collected by cytobrush of the liquid based cytology using the DNA-citoliq System kit ${ }^{\circledR}$ (Digene, São Paulo/SP, Brazil). Initially, a smear was performed in the posterior region of the oral mucosa. After this step, the smears were kept refrigerated until the time of laboratory processing.

\section{Sample processing}

The flasks with the oral smears were first homogenized in a vortex QL-901 (Quinlibei instruiments manefacture co., China) for 20 seconds. Then, an aliquot of $200 \mu \mathrm{L}$ was placed carefully with a pipette over a polycarbonate membrane (Lamigene ${ }^{\circledR}$ Digene, São Paulo / SP, Brazil). Each aliquot was subjected to press against the glass slides using a prepgene press ${ }^{\circledR}$ (Digene, São Paulo/SP, Brazil) for 10 seconds. Then, slides were immersed in absolute ethanol for about 20 minutes to fix the smear cells. Oral epithelial cells were stained with FeulgenRossenbeck modified technique. ${ }^{19}$

\section{Analysis of genotoxicity}

The identification of the slides was masked before reading. The study of the slides was performed by two examiners after training by an experienced oral pathologist. The calibration of examiners was made by simultaneous analysis of five slides. The analysis of the 1,000 cells for each participant was made by light microscopy using a binocular microscope, Nikon E200 model adapted with 10X ocular WH-H / 22 (Nikon) and PLAN objective 100x / 0.25 (Nikon). The image of the cells with nuclear changes was captured at a magnification of 400 times by a Dyno TM eye camera (Eyepiece Camera). Then, each image was analyzed careffuly. Micronuclei were characterized as small nuclear masses bounded by membrane and 


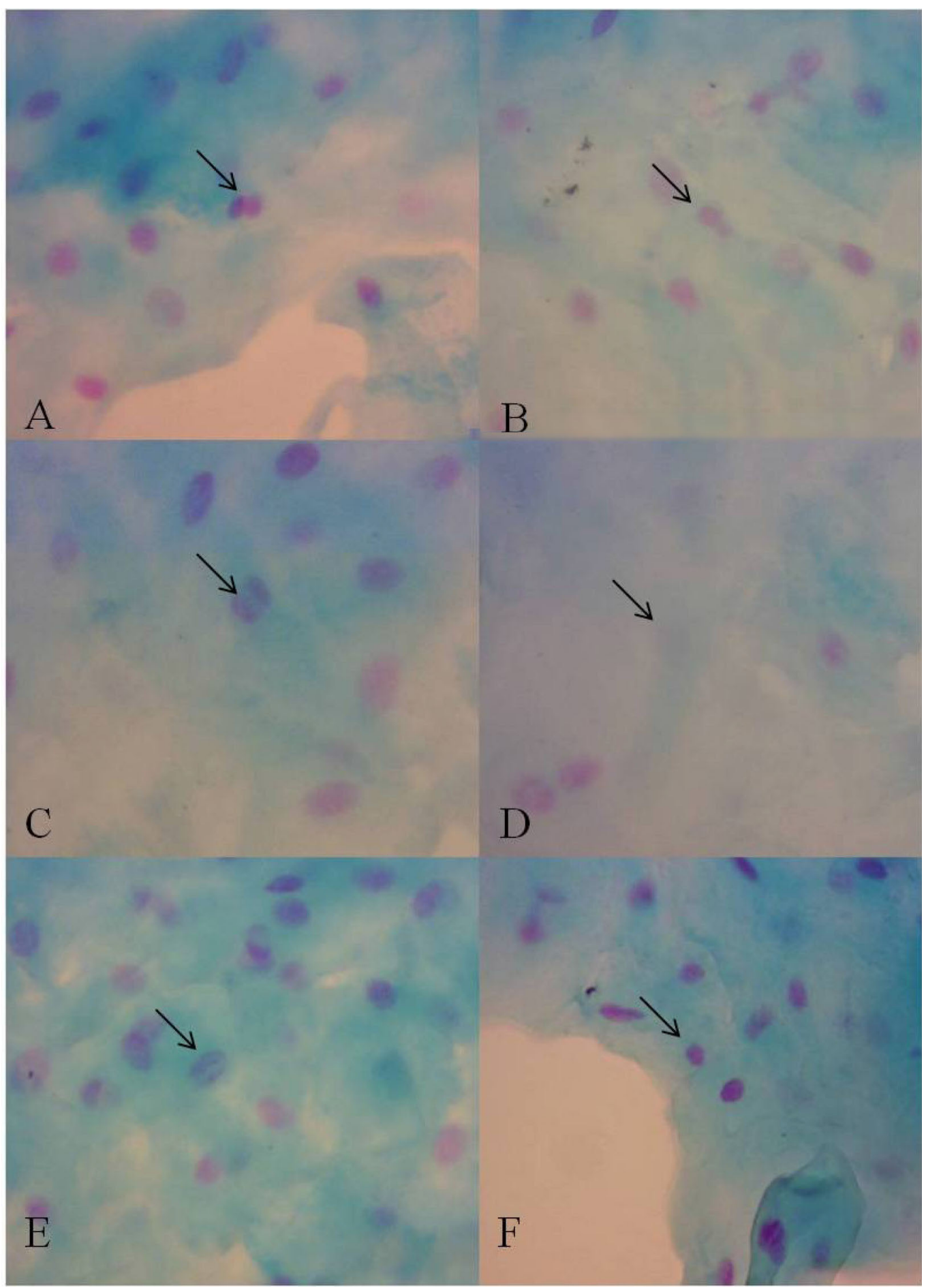

Figure 1. Oral epithelial cells of crack cocaine users showing nuclear changes. (A) binucleate cells; (B) buds; (C) broken eggs; (D) karyolysis; (E) karyorrhexis; (F) picnosis (Feulgen-Rossenbeck, 400X).

separated from the main nucleus. For confirmation of micronuclei, the following were considered: rounded shape, with a diameter less than $1 / 5$ to $1 / 3$ of the core group; located within the cytoplasm in the same focal plane; chromatin have a similar structure; color intensity and texture similar to or less; be positive Feulgen and not refractory; the edge should be evident, suggesting nuclear membrane without overlapping. ${ }^{20}$

\section{Evaluation of the cytotoxicity}

The cytotoxic potential of crack cocaine was analyzed using the criteria described by Tolbert et al. ${ }^{21}$ For this, the presence of the following nuclear abnormalities was investigated: a) Picnosis - the nucleus was seen as a small dot, dark and dense, which has no perceptible chromatin structure, b) Karyorrhexis: chromatin condensation in several particles showing 


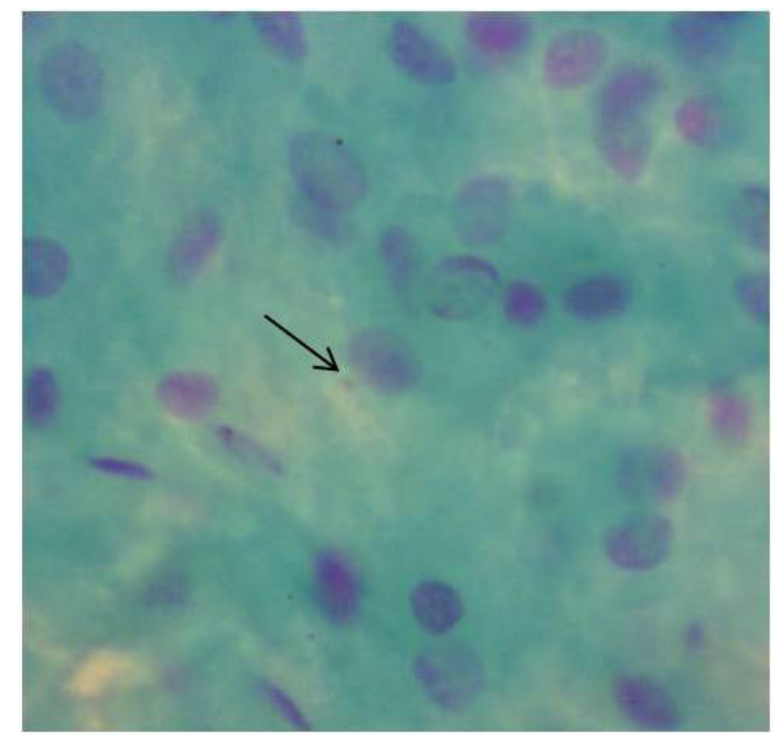

Figure 2. Oral smear of crack cocaine user showing micronucleus (arrow). (Feulgen-Rossenbeck, 400X).

fragmentation of the nucleus in small oval or rounded bodies within the intact cytoplasm. These particles were of variable number, appearing as black spots or elongated formations entirely separated from each other or connected by a thin line chromatin, c) Karyolysis: dissolution of the nucleus characterized by its absence. This nuclear change when viewed under the microscope, showed a pale and weak staining, d) Buds: cells containing a small amount of genetic material adhered to the main body as a nuclear extension, and e) Broken eggs: small amount of genetic material binds to the nucleus by a positive Feulgen filament.

\section{Statistical analysis}

Data were tabulated in the Microsoft Excel workbook on MacBook Air (Apple, USA) and then submitted to descriptive statistical analysis. The homogeneity of the data was tested by the Kolmogorov-Smirnov test. Levene's test was used before the comparison of means. Then, the Mann-Whitney test and Student $t$ test were used at a probability level of $\mathrm{p}<0.05$.

\section{RESULTS}

Thirty male subjects participated in this study (15 crack cocaine users and 15 nonusers of licit or illicit drugs). The mean age of participants was $30.2 \pm 10.65$ years (19-80). Crack cocaine users consumed an average of of $3.8 \mathrm{~g}$ of crack cocaine / day. The mean duration of drug use was 6.4 years. The frequency of cells with micronuclei and other nuclear changes in cells of users and controls is presented in Table 1. The frequency of micronuclei, karyorrhexis, karyolysis, broken eggs, buds, picnosis and binucleate cells was higher in the cells of the oral mucosa of crack cocaine users. On the other hand, the frequency of buds was higher in the control group. However, only the number of micronuclei and karyorrhexis were statistically significant. Figure 1 and 2 show binucleated cells, buds, broken eggs, karyolisis, karyorrhexis, picnosis, and micronucleus in oral epitelial cells of crack cocaine users.

\section{DISCUSSION}

The micronucleus test is used as a parameter to verify the degree of exposure and the extent of damage caused by an environmental agent to DNA. It acts as a biomarker that indicates the susceptibility of the individual to the development of cancer. ${ }^{22}$ However, the micronucleus test has its specificity increased when cellular changes indicative degenerative cell death are recorded as picnosis, karyorrhexis, karyolysis and nuclear projections (buds and broken eggs). ${ }^{23,24}$ Thus, external chemical and physical agents may be investigated for the induction of cytotoxic and genotoxic damage.

This study determined the frequency of micronuclei and nuclear changes described above in epithelial cells of the oral mucosa of crack cocaine users. The results showed that the frequency of micronuclei and karyorrhexis increased significantly. Our results corroborate the findings of some authors, such as Webber et al. and de Freitas et al. ${ }^{18,25}$ These authors observed a frequency of micronuclei and nuclear buds was significantly increased in peripheral blood lymphocytes and oral mucosa. In 2014, das Graças Alonso de Oliveira et $a l .{ }^{26}$ have investigated the frequency of micronucleus in oral mucosa of crack cocaine users too. Their results have revealed significant statistical differences of micronucleated oral mucosa cells from crack cocaine users. Furthermore, exposure to crack cocaine caused an increase of karyolysis in oral cells. On the other hand, Lima et al. ${ }^{17}$ have found no differences in the frequency of micronuclei in oral mucosal drug users. However, these authors used a sample that was concomitant use of several associated illicit drugs such as marijuana, cocaine and crack cocaine.

The literature has shown that there is a direct relationship between the combination of certain risk factors in the formation and increased frequency of micronuclei, as the effect of occupational factors combined with the socio-demographic factors: age, addictions (smoking, alcoholism), nutritional status, chronic and infectious diseases. ${ }^{27}$ Woyceichoski et al. ${ }^{28}$ has observed a significant reduction in the nuclear area, but no change of the nuclear morphology. On the other hand, an analisys of tracheobronchial cells showed that chronic exposure of smoke crack was able to induce a higher frequency of mitotic figures, changes in 
nuclear morphology and increased nucleus / cytoplasm ratio. Moreover, these nuclear changes become more representative when the crack cocaine was consumed associated with tobacco cigarettes. ${ }^{5}$

Oral mucosa cells represent the primary barrier to the route of inhalation or ingestion when crack cocaine is smoked. A higher frequency of micronuclei in cells of this population can be a strong indicator of crack ability to induce DNA damage. As is known, approximately $90 \%$ of oral cancers originate from the epithelial cells. These tumors are mostly caused by exposure to carcinogens such as tobacco and alcohol. ${ }^{29}$ Thus, a higher probability of the emergence of oral cancer in individuals who make regular use of crack cocaine associated with cigarettes and alcoholic beverages can not be ruled out. Furthermore, some authors believe that the lesions which develop in the oral mucosa caused by the crack cocaine occur much more likely due to the heat generated on the mucosa during use than the chemical action of the drug. ${ }^{30}$

Knowledge of the kinetics of the epithelial cells is extremely important for the interpretation of the results of micronucleus test. ${ }^{23}$ Some altered cells are lysed during its migration through epithelial layers. Then, these cells are deleted before reach the epitelial surface. This protective mechanism of the organism prevents the proliferation of damaged cells. ${ }^{31}$ The analysis of oral epithelial cells also provides information on nuclear changes such as karyorrhexis, karyolysis, pyknosis, broken eggs, buds and binucleate cells. This study showed a higher frequency of cells in the mucosa of crack cocaine users exhibiting karyorrhexis. In this phenomenon, the nucleus undergoes fragmentation and then disperses in the cytoplasm. The cell death by apoptosis may occur due to the large amount of damage to the DNA. The successive occurrence of these events may delay the renewal of the oral epithelium. Degenerative diseases can cause changes in the epithelium increasing susceptibility to malignant transformation, if the regenerative capacity of the tissue is supplanted. ${ }^{32}$

The mechanisms involved in the ability of cocaine to infuence the division of several cells have been hypothetized. Cocaine can induce elevation in the levels of intracelular $\mathrm{Ca}^{2+}$. This fact has been shown to be responsible for cocaine-instigation suppression of proliferation in cells culture. ${ }^{33}$ Besides, cocaine has induced PC 12 cell death by apoptosis and necrosis. These effects were verified by mitochondrial dysfunction, increase in LDH release, activation of caspase 3, decrease in Bcl-2 expression and increase in $\alpha$-spectrin cleavage. ${ }^{34}$ However, molecular studies are needed to define how cocaine exactly influences the cycle of epithelial cells of the oral mucosa.
The karyorrhexis, picnosis and karyolysis result from excessive lowering of $\mathrm{pH}$ in the dead cell which condenses the chromatin and deoxyribonucleases action and other proteases. These enzymes digest the chromatin and also promote the breakdown of the nuclear membrane. ${ }^{35}$ Some studies have indicated that karyorrhexis and karyolysis are indicators of apoptosis. ${ }^{36,37}$ Apoptosis is a programmed biological process that is genetically controlled. It is required by normal and pathological tissue development. ${ }^{23}$ On the other hand, the pyknosis and karyolysis were also observed with a higher frequency in oral cells of crack cocaine users. However, this difference was not statistically significant. Thus, it is not possible to rule out that the crack cocaine is capable of inducing cytotoxic changes in the oral mucosa.

The risk of damage due to continuous crack use is not completely clear. Thus, there is a need to investigate the impact of this drug in the short and long term on the oral mucosa. Crack smokers have a greater chance to develop diseases, especially oral cancer. Once identified, the patient may be referred for treatment. Finally, based on the findings of this study, it is recommended that individuals who have made long-term crack use often need to undergo intraoral examination. This clinical procedure is essential to identify early changes in the oral mucosa suggestive of neoplastic transformation.

\section{CONCLUSION}

This study showed that smoke from crack has genotoxic and cytotoxic potential for oral mucosa by increasing the frequency of micronuclei and karyorrhexis.

\section{ACKNOWLEDGMENT}

The authors thanks to the Financial support of the Conselho Nacional de Desenvolvimento Científico e Tecnológico (CNPq), the Laboratory of Experimental Pathology of the Pontifícia Universidade Católica do Paraná (Curitiba/PR), and Instituto de pesquisa e Tratamento do Alcoolismo (IPTA, Campo Largo/PR).

\section{CONFLICT OF INTEREST}

There are no potential conflicts of interest or any financial or personal relationships with other people or organizations that could inappropriately bias the conduct and findings of this study. 


\section{REFERENCES}

1. United Nations Office on Drugs and Crime. World Drug Report 2015. Vienna, 2015.

2. Cunha PJ, Nicastri S, Gomes LP, Moino RM, Peluso MA. Alterações neuropsicológicas em dependentes de cocaína/crack internados: dados preliminares. Rev Bras Psiquiatr. 2004; 26:103-6.

3. Kessler F, Pechansky F. A psychiatric view on the crack phenomenon nowadays. Rev Psiquiatr RS. 2008; 30:96-8.

4. Dackis CA, O'Brien CP. Cocaine dependence: a disease of the brain's reward centers. J Subst Abuse Treat. 2001; 21:111-7.

5. Barsky SH, Roth MD, Kleerup EC, Simmons M, Tashkin DP. Histopathologic and molecular alterations in bronchial epithelium in habitual smokers of marijuana, cocaine, and/or tobacco. J Natl Cancer Inst. 1998; 90:1198-205.

6. Muñoz N, Hayashi M, Bang LJ, Wahrendorf J, Crespi M, Bosch FX. Effect of riboflavin, retinol and zinc on micronuclei of buccal mucosa and of esophagus: a randomized double-blind intervention study in China. J Natl Cancer Inst. 1987; 79:687-91.

7. Benner SE, Lippman SM, Wargovich J, Lee JJ, Velasco M, Martin JW, et al. Micronuclei, a biomarker for chemoprevention trials: results of a randomized study in oral pre-malignancy. Int $\mathrm{J}$ Cancer. 1994; 59:457-9.

8. Rieger RMA, Green MM. A glossary of genetics and cytogenetics. London: Allen and Unwin. 1968.

9. Schmid W. The micronucleus test. Mutat Res. 1975; 31: 9-15.

10. Ramirez A, Saldanha PH. Micronucleus investigation of alcoholic patients with oral carcinomas. Genet Mol Res. 2002;1:246-60.

11. Stich HF, Curtis JR, Parida BB. Application of micronucleus test to exfoliated cells of high cancer risk groups: tobacco chewers. Int J Cancer. 1982; 30:553-9.

12. Lippman SM, Peters EJ, Wargovich MJ, Stadnyk AN, Dixon DO, Dekmezian RH, et al. Bronchial micronuclei as a marker of an early stage of carcinogenesis in the human tracheobronchial epithelium. Int J Cancer. 199045:811-5.

13. Stich HF, Rosin MP. Quantitating the synergistic effect of smoking and alcohol consumption with the micronucleus test on human buccal mucosa cells. Int J Cancer. 1983;31:305-8.

14. Stich HF, Rosin MP, Vallejera MO. Reduction with vitamin A and beta - carotene administration of proportion of micronucleated buccal mucosal cells in Asian betel nut and tobacco chewers. Lancet. 1984;1: 1204-6.

15. Gattás GJ, Cardoso LA, Medrado-Faria MA, Saldanha PH. Frequency of oral mucosa micronuclei in gas station operators after introducing methanol. Occup Med. 2001;51:107-13.
16. Galiotte MP, Kohler P, Mussi G, Gattás GJ. Assessment of occupational genotoxic risk among Brazilian hairdressers. Ann Occup Hyg. 2008;52:645-51.

17. Lima CF, Oliveira LU, Cabral LA, Brandão AA, Salgado MA, Almeida JD. Cytogenetic damage of oral mucosa by consumption of alcohol, tobacco and illicit drugs. J Oral Pathol Med. 2010;39:441-6.

18. Webber LP, Pellicioli A, Magnusson AS, Danilevicz CK, Bueno CC, Sant'Ana Filho M, et al. Nuclear changes in oral mucosa of alcoholics and crack cocaine users. Hum Exp Toxicol. 2016;35:184-93.

19. Feulgen R, Rossenbeck H. Mikroskopisch chemischer Nachweis einer Nucleinsäure vom Typus der thymonucleinsäure und die darauf bestehende elektive Farbung von Zellkernen in mikroskopischen Präparate. Z Physiol Chem. 1924;135:203-48. [German].

20. Celik M, Aksoy H, Yilmaz S. Evaluation of beauvericin genotoxicity with the chromosomal aberrations, sister-chromatid exchanges and micronucleus assays. Ecotoxicol Environ Saf. 2010;73:1553-7.

21. Tolbert PE, Shy CM, Allen JW. Micronuclei and other nuclear anomalies in buccal smears: methods development. Mutat Res. 1992;271:69-77.

22. Popova L, Kishkilova D, Hadjidekova VB, Hristova RP, Atanasova P, Hadjidekova VV, et al. Micronucleous test in buccal epithelium cells from patients subjected to panoramic radiography. Dentomaxillofac Radiol. 2007;36:168-71.

23. Cerqueira EM, Gomes-Filho IS, Trindade S, Lopes MA, Passos JS, Machado-Santelli GM. Genetic damage in exfoliated cells from oral mucosa of individuals exposed to X-rays during panoramic dental radiographies. Mutat Res. 2004;562:111-7.

24. Cerqueira EM, Meireles JR, Lopes MA, Junqueira VC, Gomes-Filho IS, Trindade S, et al. Genotoxic effects of X-rays on keratinized mucosa cells during panoramic dental radiography. Dentomaxillofac Radiol. 2008; 37:398-403.

25. de Freitas TA, Palazzo RP, de Andrade FM, Reichert CL, Pechansky F, Kessler F, et al. Genomic instability in human lymphocytes from male users of crack cocaine. Int J Environ Res Public Health. 2014;11:10003-15.

26. das Graças Alonso de Oliveira M, Dos Santos JN, Cury PR, da Silva VH, Oliveira NR, da Costa Padovani R, et al. Cytogenetic biomonitoring of oral mucosa cells of crack cocaine users. Environ Sci Pollut Res Int. 2014;21:5760-4.

27. Bolukbas C, Bolukbas FF, Kocyigit A, Aslan M, Selek S, Bitiren M, et al. Relationship between levels of DNA damage in lymphocytes and histopathological severity of chronic hepatitis $\mathrm{C}$ and various clinical forms of hepatitis B. J Gastroenterol Hepatol. 2006;21:610-6.

28. Woyceichoski IE, de Arruda EP, Resende LG, Machado MA, Grégio AM, Azevedo LR, et al. Cytomorphometric analysis of crack cocaine 
effects on the oral mucosa. Oral Surg Oral Med Oral Pathol Oral Radiol Endod. 2008; 105:745-9.

29. Rai HC, Ahmed J. Clinicopathological correlation study of oral squamous cell carcinoma in a local indian population. Asian Pac J Cancer Prev. 2016;17:1251-4.

30. Mitchell-Lewis DA, Phelan JA, Kelly RB, Bradley JJ, Lamster IB. Identifying oral lesions associated with crack cocaine use. J Am Dent Assoc. 1994; 125:1104-8, 1110.

31. Speit G, Schmid O, Fröhler-Keller M, Lang I, Triebig G. Assessment of local genotoxic effects of formaldehyde in humans measured by the micronucleus test with exfoliated buccal mucosa cells. Mutat Res. 2007;627:129-35.

32. Carrard VC, Costa CH, Ferreira LA, Lauxen IS, Rados PV. Teste dos Micronúcleos - Um biomarcador de dano genotóxico em células descamadas da mucosa bucal. Rev Fac Odontol Porto Alegre. 2007; 48:77-81.
33. Lidow MS, Song Z. Effect of cocaine on cell proliferation in cerebral wall of monkeys fetuses. Cerebral Cortex. 2001;11:545-51.

34. Lepsch LB, Munhoz CD, Kawamoto EM, Yshii LM, Lima LS, Curi-Boaventura MF, et al. Cocaine induces cell death and activates the transcription nuclear fator kappa-b in pc12 cells. Molecular Brain. 2009;2:3.

35. Brasileiro Filho G. Bogliolo Patologia Geral. 4th ed. Rio de Janeiro: Guanabara Koogan. 2009.

36. Celik A, Cavaş T, Ergene-Gözükara S. Cytogenetic biomonitoring in petrol station attendants: micronucleus test in exfoliated buccal cells. Mutagenesis. 2003; 18:417-21.

37. Unal M, Celik A, Ateş NA, Micozkadioğlu D, Derici E, Pata YS, et al. Cytogenetic biomonitoring in children with chronic tonsillitis: micronucleus frequency in exfoliated buccal epithelium cells. Int J Pediatr Otorhinolaryngol. 2005;69:1483-8.

(Received April 23, 2016; Accepted June 21, 2016) 